\title{
SMETANOVSKÝ DLUH ČESKÉ MUZIKOLOGIE - PÍSEMNÉ PRAMENY JAKO PŘEDMĚT ZÁJMU SMETANOVSKÉHO BÁDÁNÍ1
}

Úctyhodný objem dosavadní smetanovské literatury může snadno navodit dojem, že národní klasik je již dostatečně a zevrubně probádán. Skutečnost je však poněkud jiná a neodpovídá plně Smetanovu významu pro českou hudební kulturu. Dluhy má dosud česká muzikologie i v oblasti pramenné základny. $Z$ těch nejzávažnějších je to nevydaný tematický katalog, ${ }^{2}$ nedokončená kritická edice Smetanových děl ${ }^{3}$ a také absence kompletního vydání jeho korespondence a deníků.

Právě písemné prameny představují stále ještě nedoceněný soubor, který pokrývá prakticky celý skladatelův život ve všech jeho rovinách - rodinné, osobní, společenské i tvůrčí, včetně širšího kontextu tehdejšího hudebního a společenského života. Jejich množství, vzájemný poměr i výpovědní hodnota se v jednotlivých etapách Smetanova života proměňují v bezprostřední návaznosti na jeho aktuální životní a společenskou situaci. V dosavadní literatuře byly písemnosti využívány především jako zdroj faktografických informací. Jejich informační potenciál je však mnohem širší a v plném rozsahu ještě zdaleka využit nebyl. Odpovídající pozornost jim zatím nebyla věnována ani v ediční oblasti.

Nejrozsáhlejší celek Smetanových písemností představuje korespondence. V současné době evidujeme téměř 2300 různých typů korespondenčních sdělení:

1 Studie vznikla v rámci projektu řešeného s podporou Grantové agentury ČR (č. 14-22997S): Bedřich Smetana. Korespondence I (1840-1862). Kritická edice.

BERKOVEC, Jiří. Tematický katalog skladeb Bedřicha Smetany. 1999.

Studijní vydáni děl Bedřicha Smetany - 15 svazků této kritické edice vyšlo v letech 19401977. Osahují všechny Smetanovy opery kromě fragmentu Violy (partitury, ne však již jeho vlastní klavírní výtahy), orchestrální, sborovou a komorní tvorbu. Klavírni dílo Bedřicha Smetany - 5 svazků edice vyšlo v letech 1944-1973 (první dva svazky z roku 1944 byly ihned rozebrány a ještě v témže roce vydány podruhé, v letech 1980 a 1982 vyšly ve třetím, revidovaném vydání). V kritické edici nevydány dosud zůstávají nejvýznamnější klavírní cykly Rêves a České tance, Smetanovy skladby a úpravy pro dva a více klavírů i některé další skladby. Samostatně vyšla v roce 1962 kritická edice Smetanových písní. Podrobný přehled nejvýznamnějších souborných edic Smetanova díla viz MOJŽÍŠOVÁ, Olga. Skladby Bedřicha Smetany (výběrový soupis). In Bedřich Smetana. Doba-život-dílo-Muzeum Bedřicha Smetany. Praha: Národní muzeum, 1998, s. 117-118. 
dopisy, dopisnice, telegramy, vizitky s rukopisnými přípisy, rukopisně vyplněné úřední formuláře i prázdné obálky s adresou svědčící o existenci dopisu, čistopisy dopisů někdy nahrazují či doplňují jejich koncepty. Většina korespondence je dochována v originálních autografech (ca 67\%), některé dopisy (ca 10\%) jsou $\mathrm{k}$ dispozici jen ve fotokopiích autografü nebo v opisech a některé (ca 4\%) známe pouze z vydání tiskem. Existenci další, dnes neznámé korespondence (ca 19\%), dokládají poměrně četné zmínky ve Smetanových denících i v samotné korespondenci, další informace lze dohledat i v literatuře, časopisech, různých sbornících, starších seznamech Smetanovy korespondence, aukčních katalozích apod. Dnes známá korespondence pokrývá období 1840-1884, tedy více než dvě třetiny Smetanova života. Její množství, obsah i adresáti a odesílatelé se v průběhu let proměňovali v souvislosti s jeho životními osudy, společenským a profesním působením a s provozováním a recepcí jeho děl. S rozšiřováním Smetanových společenských a uměleckých aktivit a kontaktů postupně narůstá především osobní korespondence a korespondence s úřady a dalšími institucemi. Průběžně stoupá také množství dochovaných dopisů. Nejméně početná a do značné míry jen deníkovými záznamy a odkazy v dopisech doložená je korespondence ze 40 . let a z 1 . poloviny 50 . let 19. století. ${ }^{4}$ Její počet zréetelněji vzrostl až v letech $1857-1862$, tj. za Smetanova působení v Göteborgu a během jeho koncertních cest. ${ }^{5} \mathrm{Z}$ doby jeho nejaktivnějšího působení v pražském hudebním životě v 60 . letech a v 1 . polovině 70. let je však její množství, možná překvapivě, opět poněkud nižší. ${ }^{6}$ Největší nárůst přišel až od roku 1874, nebot' po ohluchnutí a odchodu z Prahy se písemný styk stal Smetanovým hlavním, de facto jediným komunikačním prostředkem. $\mathrm{K}$ velkému objemu korespondence $\mathrm{v}$ poslední životní dekádě výrazně přispěla také jeho rostoucí popularita a zvyšující se frekvence provozování jeho děl. ${ }^{7}$ Hlavními jazyky Smetanovy korespondence jsou čeština (zhruba 2/3) a němčina, jinými jazyky je psáno jen několik dopisů adresovaných Smetanovi. Do počátku 60. let je korespondence vedena téměř výhradně německy. Teprve po definitivním návratu do Prahy v roce 1862 se Smetana přizpůsobil změněné společenské situaci a v domácím písemném styku se přeorientoval na češtinu. ${ }^{8}$

4 Z let 1840-1856 (do Smetanova odjezdu do Švédska v říjnu 1856) je doložitelných pouze 73 korespondenčních položek.

$5 \quad$ Z této doby, tj. od listopadu 1856 do května 1862 (návrat do Čech z poslední koncertní cesty) je to 249 korespondenčních sdělení.

6 Od června 1862, kdy se Smetana definitivně usadil v Praze a začal se angažovat v hudebním životě, do srpna 1874 (počátek sluchových potíží) je dnes známo ,jen“ 401 korespondenčních jednotek, což je však vysvětlitelné tím, že mnohé záležitosti tehdy nepochybně vyřizoval prímo v osobním styku.

7 Od září 1874, kdy se Smetana vzdal svých veřejných aktivit, je do konce jeho života doloženo 1541 korespondenčních jednotek (včetně obsáhlých konvolutů blahopřejných telegramů, které obdržel při velkých oslavných akcích). Mimo tuto statistiku zůstalo pouze několik nedatovaných sdělení a dopisy, které na jeho adresu došly až po jeho smrti.

8 Podrobně k rozsahu a charakteru Smetanovy korespondence viz MOJŽÍŠOVÁ, Olga - POSPÍŠIL, Milan. S kým korespondoval Bedřich Smetana. Praha: Národní muzeum, 2009, s. IX-XVII. 
Stejně významnou, ale méně známou a stále ještě nedoceněnou součástí Smetanovy písemné pozůstalosti jsou jeho nenotové rukopisy. K některým životním obdobím či konkrétním oblastem jeho působení jsou dokonce hlavními, někdy i jedinými prameny. Na rozdíl od korespondence zůstaly pohromadě ve skladatelově pozůstalosti a lze je tedy považovat za kompletní. Pravděpodobnost nových objevů je $\mathrm{v}$ jejich př́ípadě již jen mizivá na rozdíl od korespondence, u níž lze i na základě zkušeností z nedávných let počítat s nálezy dalších pramenů nebo alespoň informací o nich.

Největším a nejcennějším souborem jsou Smetanovy deníky. Smetana si je psal průběžně od roku 1840, pouze z let 1848-1856 a 1884 se žádné záznamy nedochovaly. Lze je rozdělit do trrí skupin, které pokrývají časově jasně vymezená životní období.

První soubor obsahuje 7 sešitů studentského deníku z let 1840-1847. Smetana jej začal psát v Praze v roce 1840, přičemž na úvod připojil ještě stručný přehled událostí př̀edchozích let. ${ }^{9}$ Obsahovým těžištěm deníku je tř́leté období jeho studií na gymnáziu v Plzni v letech 1840-1843. Deník je psán jako kronika jednotlivých roků Smetanova studentského života formou denních datovaných záznamů a plnil vlastně roli důvěrníka v době, kdy se dospívající Smetana ocitl sám v cizím prostředí. Značná část záznamů se týká především jeho bohatých společenských a hudebních aktivit, další významná vrstva souvisí s jeho studentskými láskami a je výstižným dokladem Smetanova postupného citového vyzrávání, ostatním tématům je tu vymezen podstatně menší prostor. Na konec posledního sešitu dopsal Smetana v srpnu 1847 ještě stručnou retrospektivu svého pobytu v Praze, kam odešel na podzim 1843, aby si po ukončení gymnázia doplnil hudebně teoretické vzdělání. Studijní léta a s nimi také svůj studentský deník definitivně uzavřel v létě 1847, kdy ukončil studium kompozice u Josepha Proskche a působení $v$ rodině hraběte Leopolda Thun-Hohensteina, $u$ něhož si jako učitel hudby na toto studium vydělával. Jeho studentský deník je mimořádný hned v několika rovinách. Především je to jediný a při tom podrobný pramen $\mathrm{k}$ této etapě Smetanova života, který přináší i cenné údaje o existenci dalších pramenů včetně nedochované korespondence. Profilují se v něm již také některé charakteristické rysy, s nimiž se lze ve Smetanově písemném projevu setkat i v dalších obdobích. Jsou to jasně vymezené postoje a názory, výstižné a vtipné osobní charakteristiky, svědčící o vyhraněnosti jeho úsudku, velká intenzita prožitků a velmi impulsivní reakce se sklonem k afektu a nadsázce. Rovněž krasopisný rukopis a úhledná úprava jsou typické pro jeho písemnosti i autografy skladeb až do pozdního věku. Pozoruhodná je také vyspělost jeho německého písemného projevu.

Deníky si Smetana znovu začal psát v roce 1857 za pobytu ve Švédsku a v psaní pokračoval i po př́ijezdu do Prahy a na koncertních cestách. Tuto skupinu deníků uzavřel v květnu 1862 po definitivním návratu do vlasti. ${ }^{10}$ Rovněž 
„švédské“ deníky jsou poměrně podrobnou, většinou každodenní kronikou Smetanova působení v Göteborgu. K některým jeho aktivitám, zejména $\mathrm{k}$ jeho činnosti v čele zdejší amatérské pěvecké společnosti, jsou prakticky jediným zdrojem informací. Obsáhle popisují i jeho koncertní cesty (Stockholm: duben 1861, Německo, Holandsko: ř́jjen - prosinec 1861, Göteborg: březen - květen 1862) a zachycují také jeho vstup do pražského hudebního a společenského života na počátku 60. let 19. století. Dávají opět nahlédnout poměrně hluboko i do Smetanova soukromí: obsahují jediné informace o posledních dnech života Kateřiny Smetanové i o jeho vztahu k Fröjdě Benecke, partie týkající se seznámení a prvního období manželství s Bettinou Ferdinandiovou mohou osvětlit i některé příčiny pozdější krize jejich manželství. Podrobná evidence př́ijmů a výdajů v roce 1857 podává alespoň dílčí náhled do Smetanových tehdejších finančních poměrů a cenný je i soupis vlastních skladeb do roku 1858. I „,̌védské“ deníky jsou ještě významným zdrojem informací o dnes neznámých dopisech. Jsou rovněž psány německy a jejich celkový charakter vykazuje obdobné rysy jako deník studentský: přehlednou úpravu a systematičnost, s níž je Smetana přes menší pauzy a zpětně psané záznamy vedl. I v nich běžné záležitosti a fakta popisuje věcně, občas s osobně laděnými či vtipně ironickými postřehy a komentáŕi, ale v závažných osobních situacích se opět uchyluje k nadsázce a k patetickému výrazu. Také v tomto období, klíčovém pro Smetanovo další životní a umělecké směřování, zůstávají deníky nejvýznamnějšími písemnými prameny. Jejich jedinečnost nesnižuje ani narůstající množství korespondence. Ta jejich výpovědní potenciál sice někdy dubluje a stále významněji doplňuje a obohacuje, systematičnost, podrobnost a celkový objem informací deníkových záznamů však v tomto období ještě zcela nahradit nemůže.

Nejpočetnější skupina deníků z let 1862-1883 se od předchozích výrazně liší. Jsou psány již pouze česky a ve zcela jiném formátu. Smetana pro ně používal tištěné roční kalendáře, obsahující hlavně zábavná a poučná čtení, v nichž jsou vyčleněny jen jednostránkové plochy pro měsíční zápisky, prrípadně zvláštní strany pro finanční záznamy. ${ }^{11}$ Podrobně a systematicky si zde po většinu let evidoval především rodinné prřijmy a výdaje, množství ostatních záznamů v jednotlivých letech značně kolísá a zdaleka už nepokrývají toto období tak souvisle a podrobně jako předchozí deníky. Teprve od konce 60 . let počet záznamů a jejich pravidelnost pozvolna roste, $\mathrm{v} 80$. letech však $\mathrm{v}$ důsledku nemoci zase výrazně klesá. Je zřejmé, že tyto zápisky Smetana jako deník ani nezamýšlel a psal je spíše podle svého momentálního naladění a časových možností, a proto zde i k některým jeho významným aktivitám a důležitým událostem nenajdeme praktic-

až do května 1862. Otevřeným problémem zůstává existence, případně osud deníku na rok 1858.

11 Např. Všeobecný domácí sekretář, Praktický kalendář obsahu všeužitečného pro každého občana; Posel z Prahy, Kalendář zábavný a poučný; Kalendář Koruny české; Velký Slovanský Kalendář a další. 
ky žádné informace. ${ }^{12}$ Podle těchto kalendářových zápisků se Smetana v roce 1875 pokusil pokračovat i v psaní deníku, a to zpětně od roku $1862 .{ }^{13}$ Došel však jen do roku 1866, pak už pouze stručně shrnul některé okolnosti svého angažmá v Prozatímním divadle a na deník definitivně rezignoval. Množstvím a rozsahem informací tak již nejsou tyto zápisníky dominantními prameny, avšak jistou míru unikátnosti a nezastupitelnosti si nadále ponechávají zejména $\mathrm{v}$ rodinné a ryze osobní rovině a také v dokumentaci Smetanových finančních poměrů, která takto podrobně $\mathrm{v}$ jiných obdobích a pramenech $\mathrm{k}$ dispozici není. $\mathrm{V}$ dalších oblastech už většinou poskytuje mnohem podrobnější a všestrannější informace především jeho korespondence. ${ }^{14}$

Korespondenci a deníky doplňuje ještě skupina rukopisů souvisejících s některými konkrétními oblastmi Smetanova působení. Katalogy žáků z let 1848-1861 a 1863-1866 jsou vlastně jedinými dokumenty k jeho pedagogické činnosti, které $\mathrm{v}$ dopisech a $\mathrm{v}$ denících věnoval jen okrajovou pozornost. Vedle jmenných seznamů s evidencí docházky a plateb za výuku obsahují v některých případech i další cenné údaje o klientele jeho hudebních ústavů i o privátních žácích. Vyčíst z nich lze alespoň dílčí informace také o rozsahu a uspořádání výuky a poměrně přesný obraz poskytují o Smetanových př́ijmech z vyučování, které představovaly vždy významnou položku v jeho rozpočtu. Další soubor obsahuje rukopisy související s provozem opery Prozatímního divadla. Po celé své působení ve funkci prvního kapelníka české opery si Smetana vedl vlastní statistiky repertoáru i operního provozu. A další rukopisy obsahují poměrně podrobné záznamy o provozování a finančních výnosech jeho oper v letech 1866-1882. V sešitě s repertoárovou statistikou je obsažen také Smetanův soupis vlastních skladeb z roku 1875 s doplňky z pozdějších let.

Písemné prameny nabízejí kromě faktografie také další roviny pohledu na osobnost Bedřicha Smetany. Některé okruhy dosud plně nevyužitých informací tak mohou významně rozšírít dosavadní poznatky nebo korigovat některá ustálená či tradovaná tvrzení o Smetanovi a mohou v jeho biografii objevit i nové okolnosti, objasnit dosud sporné nebo zatím opomíjené momenty, a to nejen z hlediska hudebně historického ale i mezioborového.

Teprve v nedávné době se např. stala předmětem důkladného lingvistického výzkumu Smetanova čeština a němčina včetně kontextu jazykové problematiky jeho doby. $\mathrm{V}$ jeho jazykové biografii byl zevrubně popsán proces osvojování a užívání obou jazyků $\mathrm{v}$ jednotlivých obdobích a v různých sférách jeho osobního života i profesního působení a také na pozadí změn v postavení obou

12 Např. k dění okolo konstituování Umělecké besedy, jehož se velmi aktivně účastnil, k jeho sbormistrovství v Hlaholu, ani k období jeho kapelnictví v Prozatímním divadle, nekomentuje tu vůbec vyhrocené polemiky v tisku, jejichž terčem se stal na přelomu 60. a 70. let.

V lednu 1875 navázal v posledním ,švédském“ deníku tam, kde v květnu 1862 po návratu ze Švédska přestal.

14 Podrobná charakteristika jednotlivých skupin Smetanových deníků viz MOJŽÍŠOVÁ, Olga. Deniky Bedřicha Smetany. Jejich pramenná hodnota a edični problematika. Praha 2013. Disertační práce. Univerzita Karlova. Filozofická fakulta. Ústav hudební vědy. 
jazyků v souvislosti s rostoucím národním uvědoměním a s postupnou jazykovou emancipací české společnosti. Důkladná analýza korespondence a částečně i deníků přinesla podrobné charakteristiky jednotlivých stránek Smetanovy češtiny a němčiny, jejich pravopisu, gramatiky, slovní zásoby, hláskosloví, syntaxe i vzájemného vlivu a prolínání obou jazyků. ${ }^{15}$ Získané poznatky vysvětlují řadu charakteristických rysů a zvláštností Smetanova písemného projevu a korigují tak dosavadní ustálený a často zjednodušený pohled na jeho jazykové schopnosti, především na problematickou úroveň jeho češtiny. Dokládají také bohatou slovní zásobu a značnou stylistickou obratnost i obraznost Smetanova vyjadřování, a to nejen v němčině ale i v češtině. Zejména $\mathrm{v}$ oblasti ediční tak mohou významně přispět k poučenější interpretaci jeho jednotlivých jazykových zvláštností.

Informace $\mathrm{z}$ písemných dokumentů byly průběžně využivány i v oblasti lékařské vědy v souvislosti s výzkumem různých stránek Smetanova zdravotního stavu. Pochopitelně to byly především písemné zmínky, které se bezprostředně týkaly jeho konkrétních zdravotních problémů. V 90. letech se ale do př́mé souvislosti s touto problematikou jako důkazní materiál dostaly zcela nově jako projev či důsledek jeho aktuálního zdravotního stavu i jeho četné a dosud spíše za kuriozitu považované deníkové záznamy o počasí. ${ }^{16}$

Rovněž z hlediska psychologie Smetanovy osobnosti jsou písemnosti bohatým a zatím nepř́liš prozkoumaným zdrojem informací. Deníky a zčásti i korespondence prezentují někdy velmi bezprostředně a bez zábran jeho názory, postoje i reakce v konkrétních banálních i závažných osobních a profesních situacích, lze z nich vyčíst leccos o jeho povahových rysech, které se mohly do jisté míry podílet i na neúspěchu některých jeho aktivit či na některých problematických a konfliktních osobních vztazích. Odrážejí také peripetie jeho citového života a partnerských vztahů od prvních platonických lásek až po závažné problémy jeho druhého manželství. Rovněž izolace od reality v době hluchoty výrazně změnila jeho vnímání okolního světa a vedla tak někdy k neadekvátním stanoviskům a reakcím v soukromé i profesní sféře.

15 Viz např.: NEKULA, Marek - RYCHNOVSKÁ, Lucie. Smetanova čeština v dobovém kontextu. Hudebni věda 2010, roč. 47, č. 1, s. 43-76. NEKULA, Marek - RYCHNOVSKÁ, Lucie. Jakou češtinu užíval Bedřich Smetana? Musicalia 2012, roč. 4, č. 1-2, s. 6-20. NEKULA, Marek - RYCHNOVSKÁ, Lucie. Jazyková biografie Bedřicha Smetany a jazyk jeho korespondence se zřetelem ke gramatickým jevům. In Soukromá korespondence jako lingvistický pramen. Z. Hladká a kol. Brno: Masarykova univerzita, 2013, s. 99-136. RYCHNOVSKÁ, Lucie. ...zapovidám, by se kontrolirovalo, jest-li já pracují... Aneb o vlivu němčiny na český jazyk Bedřicha Smetany. In Varia XIX. Zbornik plných príspevkov z XIX. kolokvia mladých jazykovedcov. Trnava-Modra-Harmónia 18. - 20. 11. 2009. [CD-ROM]. J. Hladký - L. Rendár (eds.). Trnava: Trnavská univerzita v Trnave, 2010, s. 322-324. RYCHNOVSKÁ, Lucie. Korespondence Bedřicha Smetany z hlediska pravopisného. In Dějiny českého pravopisu (do r. 1902). M. Čornejová - L. Rychnovská - J. Zemanová (eds.). Brno: Host Masarykova univerzita, 2010, s. 402-412.

16 RAMBA, Jiří. Slavné české lebky. Antropologicko-lékařské nálezy jako pomocníci historie. Praha: Galén, 2005, s. 153-298. 
Unikátní jsou i Smetanovy podrobné a systematické finanční záznamy, které si vedl od 60 . let. Podrobně specifikované měsíční př́ijmy a výdaje, včetně evidence případných přebytků a deficitů a celoročních sumarizací dokládají zdroje jeho př́ijmů i spektrum a výši jeho výdajů, proměnlivost a frekvenci jejich jednotlivých položek. Poskytují tak obsáhlé informace o struktuře a vzájemném poměru Smetanových př́ijmů a výdajů $v$ jednotlivých měsících i letech a ve svém souhrnu vypovídají o jeho celkové ekonomické situaci v daném období. Lze si podle nich do jisté míry udělat i představu o běžném každodenním životě Smetanových, např. o chodu domácnosti, o životním stylu a společenské úrovni, na níž se rodina pohybovala. Ve světle těchto záznamů nebyly Smetanovy finanční poměry rozhodně špatné až zoufalé, jak se někdy traduje, většinou na základě některých jeho emotivních výroků, vytržených však ze širších souvislostí. ${ }^{17}$

Nutnost vydání Smetanových písemností si uvědomovaly všechny generace badatelů. Po skladatelově smrti zůstaly písemné prameny roztroušeny ve vlastnictví soukromých subjektů, zejména rodiny. Ochota a vstř́cnost jejich majitelů byla však tehdy poměrně velká, a tak se začaly díky aktivitám jednotlivých badatelů poměrně hojně, byt' spíše živelně uveřejňovat především Smetanovy dopisy - jednotlivě nebo v menších souborech byly publikovány již od poloviny 80 . let časopisecky, později následovaly i větší výbory v knižním vydání. Vedle prưřezů Smetanovou korespondencí, sestavených především z dosud neznámých dopisů jako první velký komplet v časopise Dalibor ve 2. polovině 80 . let a knižní vydání Karla Teigeho, ${ }^{18}$ se začaly objevovat i soubory korespondence s konkrétními osobnostmi: např. Marie Calma uveřejnila alespoň část Smetanových dopisů Bettině Ferdinandiové ${ }^{19}$ a Arnošt Kraus publikoval korespondenci se švédskými přáteli. ${ }^{20}$ Vladimír Balthasar vydal Smetanovy dopisy Josefu Srbovi, k nimž o 20 let později přidal Jaroslav Čeleda vydání Srbových dopisů Smetanovi. ${ }^{21}$

17 Podrobně k této problematice viz MOJŽÍŠOVÁ, Olga: Die finanzielle Lage Bedřich Smetanas im Lichte der Quellen. Acta Universitatis Carolinae - Philosophica et Historica - Miscellanea Musicologica, v tisku.

18 TEIGE, Karel (ed.). Smetanovy dopisy. Řada první (I-LIII), Řada druhá (I-XXV), Řada třetí (I-XVII). Dalibor, 1885, roč. 7, č. 18-23, 25-28, 30-31, 35-39, 41-48; 1886, roč. 8, č. 18, 22-24, 26-29, 31, 34-35; 1887, roč. 9, č. 30, 32-35, 44, 47-48. TEIGE, Karel. Přispěvky k životopisu a umělecké činnosti Mistra Bedřicha Smetany. II. Dopisy Smetanovy. Kommentovaný výbor šedesáti čtyř Mistrových dopisů. Praha: Fr. A. Urbánek, 1896.

CALMA, Marie. Milostné listy Bedřicha Smetany. Světozor. 1909, č. 23, s. 546-547, č. 24, s. 570-571, č. 26 , s. $619-620$, č. 27 , s. 641-642, č. 28 , s. 665-666, č. 29, s. 689-690, č. 30, s. $713-715$, č. 31 , s. 737 , č. 33, s. 785-786, č. 35, s. 833-834.

KRAUS, Arnošt. Bedřich Smetana v Göteborgu. Zvláštní otisk z: Věstník České akademie císaře Františka Josefa pro vědy, slovesnost a umění. 1906, roč. 15. Původně v časopise na pokračování v č. 1-5, s. 1-8, 81-87, 283-289, 356-364, 401-413. KRAUS, Arnošt. Smetana v Göteborgu. Praha: J. Otto, 1925.

21 BALTHASAR, Vladimír. Bedřich Smetana: Část II. Dopisy B. Smetany na J. Srba-Debrnova. Vydání souborné. Praha: Mojmír Urbánek, 1924, s. 93-310. ČELEDA, Jaroslav. Smetanuv druh sděluje: Život a dílo Josefa Srba-Debrnova. Praha: Edvard Menšl, 1945, s. $175-195$. 
Časopisecky i knižně vyšly také některé edice vzájemné korespondence, např. s Janem Nerudou, Janem Ludevítem Procházkou, Eliškou Krásnohorskou a Josefem Jiránkem. ${ }^{22}$ Přestože tak byla postupně zveřejněna významná část Smetanovy korespondence, zůstalo z ní nemalé množství stále nevydáno. Úroveň stávajících edic byla velmi různorodá - neř́ídily se žádnými jasně stanovenými edičními pravidly a texty dopisů editoři celkem libovolně upravovali podle současných pravidel, německé dopisy byly většinou překládány. Zejména v počátcích vycházely dopisy často i bez věcných komentářů $\mathrm{k}$ jejich obsahu. ${ }^{23}$

Obdobná situace byla i u Smetanových deníků. Až počátkem 20. století z nich první badatelé a uveřejnili alespoň vybrané partie, v nichž většinou kombinovali různě obsáhlé autentické pasáže s převyprávěním či komentářem jejich dalšího obsahu. Josef Srb takto zveřejnil obsah švédských deníků z let $1859-1862,{ }^{24}$ studentským deníkem se poprvé zabývali Ladislav Dolanský a po něm Alois Hnilička, který z něj publikoval již dosti obsáhlé pasáže. ${ }^{25}$ Cílem těchto prací bylo $z$ dosud neznámých deníků uveřejnit co nejvíce informací a vyplnit tak dosavadní bílá místa ve Smetanově biografii. Nejdůkladněji studentský deník vytěžil Zdeněk Nejedlý ve 3 . a zejména ve 4 . svazku své smetanovské monografie, v nichž především jeho prostřednictvím vykládá Smetanovu osobnost i př́slušná období jeho života. ${ }^{26} \mathrm{O}$ využití dalších deníků se již nikdo obdobným způsobem nepokusil. Jako samostatné edice $\mathrm{z}$ nich byly publikovány $\mathrm{v}$ časopisech nebo jako př́ležitostné drobné publikace pouze zlomky - malé tematicky úzce zaměřené výbory, někdy spíše jen soubory vybraných citátů, jejichž editorská úroveň byla obdobná jako u korespondence. ${ }^{27}$

22 REKTORYS, Artuš. Neruda a Smetana. Dalibor. 1908, roč. 30, č. 32-33, s. 247-251. LÖWENBACH, Jan. Bedřich Smetana a Dı Ludevit Procházka: Vzájemná korespondence. Praha: Umělecká beseda, 1914. OČADLÍK, Mirko. Eliška Krásnohorská - Bedřich Smetana: Vzájemná korespondence. Praha: Topičova edice, 1940. PISTORIUSOVÁ, Blažena - PISTORIUS, Luboš (ed.). Smetanův žák vzpominá: Vzpomínky a korespondence Josefa Jiránka. Praha: Topičova edice, 1941.

23 Podrobný souhrnný přehled a charakteristika dosavadních vydání Smetanovy korespondence viz MOJŽÍŠOVÁ, Olga - POSPÍŠIL, Milan. Dávný dluh české muzikologie. Historie vydávání korespondence Bedřicha Smetany. Hudebni věda 2010, roč. 47, č. 1, s. 5-17.

24 DEBRNOV, J. S. Z denníků Bedřicha Smetany. Praha: Mojmír Urbánek, 1902.

25 DOLANSKÝ, Ladislav. Bedřich Smetana v letech 1840-1847. Naše doba 1903, roč. 10, s. 241-246, 360-365. HNILIČKA, Alois. Friedrich Smetana's Jugendjahre. Union (Hauptblatt) 1915 , roč. 54, č. 104, 117, 124, 132, 146, 157, 166, 174, 188, 199, 208, 220, 243, 269 , 338, 359; 1916, roč. 55, č. 20, 48, 77, 124, 131, 144, 152, 157, 163, 177.

26 Nejedlý, Zdeněk. Bedřich Smetana III. Praha a venkov. Praha: Hudební matice Umělecké besedy, 1929. NejedLÝ, Zdeněk. Bedřich Smetana. IV. Ve společnosti. Praha: Melantrich, 1933.

27 Opera „Tajemství“ ve Smetanových dennících. Hudební revue 1908, roč. 1, č. 8, s. 377-379. [NEJEDLÝ, Zdeněk]. B. Smetany politické záznamy z let 1868-1873. Smetana 1918, roč. 9 , č. 1, s. 4-6. NEJEDLÁ, Marie. Doklady o stycích Smetanových s Podještědím a K. Světlou. 1. Z denníků B. Smetany. In Od Ještěda k Troskám 1924, roč. 2, č. 7, s. 176-178. BARTOŠ, Josef (ed.). Z deníků Bedřicha Smetany. Praha: vlastním nákladem dr. Viléma Pospíšila, 1938. BARTOŠ, František (ed.). Studentské vánoce Bedřicha Smetany r. 1840 a 1841. Praha: 
Požadavek souborného vydání Smetanových písemných pramenů se poprvé objevil v roce 1919, kdy jej Zdeněk Nejedlý zařadil do nového ambiciózního programu Sboru pro postavení Smetanova pomníku v Praze (od roku 1931 Společnost Bedřicha Smetany). Sbor také v roce 1926 založil Smetanovo muzeum a o dva roky později se zasloužil o zakoupení Smetanovy pozůstalosti, která byla do muzea předána v letech 1929-1932. Vznik monograficky specializovaného pracoviště umožnil teprve systematické shromažd’ování a evidenci smetanovských pramenů - v následujících letech se tak podařilo podstatně zkompletovat Smetanovu korespondenci, zejména odeslanou, která nebyla součástí pozůstalosti. V letech 1939-1941 zpracovalo muzeum interní soupisy tehdy známé odeslané a přijaté korespondence, z nichž vyšel v roce 1960 i první publikovaný soupis Mirko Očadlíka, který posléze rozšiřil František Bartoš. ${ }^{28}$ Od roku 1941 připravovali František Bartoš a Zdeněk Němec komentovanou edici rozsáhlého výboru Smetanových dopisů, projekt však ukončila Němcova tragická smrt. I v ní měly být německé dopisy v českém překladu a transkripce textů ukazují, že se i přes zachování některých jazykových zvláštností rovněž neobešla bez řady úprav. ${ }^{29}$ Deníky se muzeum začalo soustavněji zabývat až od přelomu 40. a 50. let, kdy pořídilo první strojopisné opisy většiny deníků i kalendářových zápisníků. V 60 . letech byly znovu přepsány ,švédské“ deníky a v 70. letech vznikl, tentokrát již podle jasných transkripčních pravidel, nový kompletní přepis studentského deníku. K druhému sešitu se dochoval i obsáhlý svazek textově kritických poznámek, obsahující také některé věcné vysvětlivky. Pravděpodobně se v tomto př́ípadě již jednalo o př́ípravu edičního záměru. Paralelně se tehdy v muzeu pořizovaly, snad za týmž účelem, i přepisy Smetanovy korespondence, také v nich se však víceméně nahodile některé jazykové zvláštnosti zachovávaly a jiné upravovaly. Jasná představa o koncepci a pravidlech vydání písemných pramenů však tehdy stále neexistovala a nebyla zréejmá ještě ani sto let po Smetanově úmrtí. ${ }^{30} \mathrm{Za}$ dlouholetou váhavostí a bezradností a odsouváním jejich kompletního vydání na pozdější dobu byly však také některé objektivní okolnosti, které v průběhu předchozích desetiletí využití korespondence a deníků i konkrétní formy jejich uveřejňování nepochybně ovlivnily.

A. J. Boháč, 1939. OČADLÍK, Mirko (ed.). Zápisky Bedřicha Smetany o Mladě Boleslavi. Mladá Boleslav, Klub př́tel umění v Mladé Boleslavi, 1949. Podrobný historický přehled využití a zpř́stupnění Smetanových deníků včetně publikovaných i nerealizovaných edičních pokusů viz MOJŽÍŠOVÁ, op. cit., s. 157 (pozn. 14).

OČADLÍK, Mirko. Soupis dopisů Bedřicha Smetany. Miscellanea musicologica. 1960, roč. 15, sv. III, s. 1-134. BARTOŠ, František. Př́spěvky k soupisu dopisů Bedřicha Smetany. Hudebni véda. 1964, roč. 1, č. 4, s. 645-682.

Př́ípravné materiály $\mathrm{k}$ tomuto projektu obsahuje pozůstalost Františka Bartoše uložená v hudebně historickém oddělení Českého muzea hudby v Praze (inventár̆ fondu S 48, zpracovala: Jana Vyšohlídová, 1982).

30 Viz MALÝ, Miloslav. Současný stav, potřeby a perspektivy péče o dílo Bedřicha Smetany. In Sto let odkazu Bedřicha Smetany. Př́spěvky a studie z konference hudebnè vědecké oblasti Svazu českých skladatelů a koncertních umělcù v Praze. Praha: Svaz českých skladatelů a koncertních umělců, 1985, s. 195-207. 
Hlavně zpočátku to byla jejich omezená dostupnost a využitelnost. Především ze strany rodiny byly tehdy stanoveny limity, co bylo možné zveřejnit, a ke zdrženlivosti vedly badatele i obecné etické ohledy nejen ke Smetanovi ale i k rodině a dalším žijícím současníkům. V důsledku toho docházelo při publikování občas ke krácení textů a $\mathrm{k}$ vynechávání citlivých partií. Zatímco u některých pramenů tyto překážky časem zmizely, některá tabu a etické zábrany přetrvávaly velmi dlouho, prakticky až dodnes. I proto zůstaly nevydány některé části rodinné korespondence a např. deníky z let 1879-1883 nebyly na přání rodiny ani v muzeu běžně př́stupné.

Dalším faktorem byla skutečnost, že již od konce 19. století vznikal víceméně ustálený a do jisté míry idealizovaný obraz Smetanovy umělecké i lidské osobnosti a jeho významu v kontextu českého hudebního a společenského života a nebylo př́liš žádoucí jej nějakým způsobem narušovat, což by s sebou kompletní zveřejnění deníků a některých částí korespondence nepochybně přineslo.

Problém představovala také otázka jazyková - Smetanova němčina i čeština. Zpočátku převažovala popularizační snaha zpř́istupnit neznámé prameny široké veřejnosti, a tudíž byly německy psané dokumenty uveřejňovány až na výjimky $\mathrm{v}$ českých překladech. Je otázkou, zda by v 1 . polovině 20 . století, ale také v poválečných letech byla ze strany široké veřejnosti akceptovatelná edice písemností národního klasika v němčině. $Z$ editorského hlediska nepředstavovala Smetanova němčina př́liš velký problém, o to více jím byla Smetanova čeština. Ve všech výše uvedených edicích je zřejmý rozpor mezi úsilím editorů zachovat specifika Smetanovy češtiny a zároveň tuto jeho češtinu v různé míře upravovat. Tyto úpravy byly evidentně vedeny především snahou vyretušovat chyby a stylistické neobratnosti, které by mohly být vykládány jako důkaz Smetanovy špatné znalosti mateřského jazyka.

Důležitým faktorem, který problém vydání Smetanovy písemné pozůstalosti významně ovlivnil, bylo také pořadí priorit při zveřejňování pramenů $\mathrm{k}$ jeho životu a dílu. Na prvním místě stálo vždy skladatelovo dílo. Zpočátku to byla především snaha vydat skladby dosud neznámé a nepublikované včetně chybějících klavírních výtahů oper. V meziválečném období, kdy hudební vydavatelství již běžně produkovala praktické edice Smetanových skladeb, se pozornost upnula k souborné kritické edici. Př́íprava poměrně rychle vycházejících svazků Studijniho vydání děl Bedřicha Smetany i samostatné edice klavírní tvorby zaměstnávala až do 80 . let 20 . století přední smetanovské badatele, kteří se na nich podíleli individuálně i v rámci editorských týmů, a odčerpala tak prakticky veškerou jejich pracovní kapacitu. Nepochybně i kvůli vytížení prací na edici se již František Bartoš, disponovaný editorskými zkušenostmi a hlubokou znalostí celé pramenné základny i pro vydávání písemných pramenů, nevrátil k projektu souborného vydání korespondence. Ani Smetanovo muzeum nemělo potřebné kapacity pro vědeckou práci, nebot' se $\mathrm{v}$ rámci své působnosti orientovalo převážně na výchovně vzdělávací a výstavní činnost. A tak zůstala korespondence nadále roztř́šstěna a zakonzervována ve starších edicích a deníky i další rukopisy, které byly v pořadí vždy až za korespondencí, již za těchto okolností šanci 
na vydání neměly a na své komplexní zhodnocení a zpř́istupnění tak stále ještě čekají. ${ }^{31}$

Olga Mojžíšová (olga_mojzisova@nm.cz), Národní muzeum, České muzeum hudby, Praha.

\section{ABSTRACT \\ THE DEBT OF CZECH MUSICOLOGY TO SMETANA: NON-MUSI- CAL MANUSCRIPTS AS A FOCUS OF INTEREST OF SMETANA RE- SEARCH}

The correspondence, diaries, and some other non-musical manuscripts of Smetana constitute an important set of sources for Smetana research that has not yet been made fully accessible or been fully utilized, and their complete publication remains a major unrealized desideratum for Czech musicology. This study provides a brief characterization of various groups of these documents and of their publication history to date, including failed attempts at collected edition projects. It also points out some types of information neglected or perceived only marginally so far that can substantially augment or correct knowledge about Smetana from a musicological as well as interdisciplinary viewpoint, and describes some objective circumstances that in the past have affected efforts to make them accessible and resulted in postponement of complete publication.

Key words

Bedřich Smetana, written sources, correspondence, diaries, edition

\section{Bibliography}

BALTHASAR, Vladimír. Bedřich Smetana. Praha: Mojmír Urbánek, 1924.

BARTOŠ, František (ed.). Studentské vánoce Bedřicha Smetany r. 1840 a 1841. Praha: A. J. Boháč, 1939.

BARTOŠ, František. Př́ispěvky k soupisu dopisů Bedřicha Smetany. Hudební věda. 1964, roč. 1, č. 4 , s. 645-682.

BARTOŠ, Josef (ed.). Z deniků Bedřicha Smetany. Praha: vlastním nákladem dr. Viléma Pospíšila, 1938.

CALMA, Marie. Milostné listy Bedřicha Smetany. Světozor. 1909, č. 23, s. 546-547, č. 24, s. 570571, č. 26, s. 619-620, č. 27, s. 641-642, č. 28, s. 665-666, č. 29, s. 689-690, č. 30, s. 713-715, č. 31, s. 737, č. 33, s. 785-786, č. 35, s. 833-834.

ČECHOVÁ, Olga - FOJTÍKOVÁ, Jana. Bedřich Smetana. Inventář fondu S 217. Praha: Národní muzeum - Muzeum české hudby - oddělení hudebního archivu, 1984 [strojopis].

ČELEDA, Jaroslav. Smetanův druh sděluje. Praha: Edvard Menšl, 1945.

DEBRNOV, J. S. Z denniki̊ Bedřicha Smetany. Praha: Mojmír Urbánek, 1902.

31 Od roku 1986 do počátku 90. let probíhala v Muzeu Bedřicha Smetany první etapa př́pravných prací ke kritické edici Smetanovy korespondence. K př́ípravě projektu se muzeum vrátilo v letech 2005-2011 v rámci výzkumného záměru Národního muzea Osobnosti české vědy a kultury (MK 00002327202) a v letech 2012-2013 práce pokračovala $\mathrm{v}$ rámci vědeckovýzkumné činnosti Národního muzea. Od roku 2014 (projekt s podporou Grantové agentury ČR) se připravuje vydání prvního svazku edice, který by měl v roce 2015 zpř́istupnit Smetanovu korespondenci z let 1840-1862. 
HNILIČKA, Alois. Friedrich Smetana's Jugendjahre. Union (Hauptblatt) 54, 1915, č. 104, 117 , $124,132,146,157,166,174,188,199,208,220,243,269,338,359 ; 55,1916$, č. 20, 48, 77 , 124, 131, 144, 152, 157, 163, 177.

KRAUS, Arnošt. Smetana v Göteborgu. Praha: J. Otto, 1925.

LÖWENBACH, Jan. Bedřich Smetana a Ď Ludevit Procházka: Vzájemná korespondence. Praha: Umělecká beseda, 1914.

MALÝ, Miloslav. Současný stav, potřeby a perspektivy péče o dílo Bedřicha Smetany. In: Sto let odkazu Bedřicha Smetany. Příspěvky a studie z konference hudebně vědecké oblasti Svazu českých skladatelů a koncertních umělců v Praze. Praha: Svaz českých skladatelů a koncertních umělců, 1985, s. 195-207.

MOJŽǏŠOVÁ, Olga (ed.). Bedřich Smetana. Doba - život - dílo - Muzeum Bedřicha Smetany. Praha: Národní muzeum, 1998.

MOJŽÍŠOVÁ, Olga. Deníky Bedřicha Smetany. Jejich pramenná hodnota a edični problematika. Praha 2013. Disertační práce. Univerzita Karlova. Filozofická fakulta. Ústav hudební vědy.

MOJŽǏŠOVÁ, Olga - POSPÍŠIL, Milan. S kým korespondoval Bedřich Smetana. Praha: Národní muzeum, 2009.

MOJŽǏŠOVÁ, Olga - POSPÍŠIL, Milan, Milan. Dávný dluh české muzikologie. Vydání korespondence Bedřicha Smetany. Hudebni véda 47, 2010, č. 1, s. 5-17.

MOJŽÍŠOVÁ, Olga - PospišslL, Milan. Projekt kritické edice korespondence Bedřicha Smetany. Současný stav. Hudební věda 47, 2010, č. 1, s. 19-42.

MOJŽÍŠOVÁ, Olga - POSPÍŠIL, Milan. Bedřich Smetana a jeho korespondence. Praha: Národní muzeum, 2011.

NEJEDLÁ, Marie. Doklady o stycích Smetanových s Podještědím a K. Světlou. 1. Z denníků B. Smetany. In: Od Ještěda k Troskám 2, 1924, č. 7 (Smetanovo číslo), s. 176-178.

NEJEDLÝ, Zdeněk. Bedřich Smetana. I. Doma. Praha: Hudební Matice Umělecké besedy, 1924.

NEJEDLÝ, Zdeněk. Bedřich Smetana III. Praha a venkov. Praha: Hudební matice Umělecké besedy, 1929.

NEJEDLÝ, Zdeněk. Bedřich Smetana. IV. Ve společnosti. Praha: Melantrich, 1933.

NEKULA, Marek - RYCHNOVSKÁ, Lucie. Smetanova čeština v dobovém kontextu. Hudebni véda 47, 2010, č. 1, s. 43-76.

NEKULA, Marek - RYCHNOVSKÁ, Lucie. Jakou češtinu užíval Bedřich Smetana? Musicalia 4, 2012, č. 1-2, s. 6-20.

OČADLÍK, Mirko (ed.). Zápisky Bedřicha Smetany o Mladě Boleslavi. Mladá Boleslav: Klub př́átel umění v Mladé Boleslavi, 1949.

OČADLÍK, Mirko. Elǐ̌ka Krásnohorská - Bedřich Smetana: Vzájemná korespondence. Praha: Topičova edice, 1940.

OČADLÍK, Mirko. Soupis dopisů Bedřicha Smetany. Miscellanea musicologica. 1960, roč. 15, sv. III, s. 1-134.

PISTORIUSOVÁ, Blažena - PISTORIUS, Luboš (ed.). Smetanův žák vzpomíná: Vzpomínky a korespondence Josefa Jiránka. Praha: Topičova edice, 1941.

RAMBA, Jiří. Slavné české lebky. Antropologicko-lékařské nálezy jako pomocníci historie. Praha: Galén, 2005, s. 153-298.

REKTORYS, Artuš. Neruda a Smetana. Dalibor. 1908, roč. 30, č. 32-33, s. 247-251.

TEIGE, Karel. Př́spěvky k životopisu a umělecké činnosti Mistra Bedřicha Smetany. II. Dopisy Smetanovy. Kommentovaný výbor šedesáti čtyr̆ Mistrových dopisů. Praha: Fr. A. Urbánek, 1896. 